\title{
Political Parties and the Business Cycle in the United States, 1948-1984
}

\section{Citation}

Alesina, Alberto, and Jeffrey Sachs. 1988. Political parties and the business cycle in the United States, 1948-1984. Journal of Money, Credit and Banking 20(1): 63-82.

\section{Published Version}

doi:10.2307/1992667

\section{Permanent link}

http://nrs.harvard.edu/urn-3:HUL.InstRepos:4553026

\section{Terms of Use}

This article was downloaded from Harvard University's DASH repository, and is made available under the terms and conditions applicable to Other Posted Material, as set forth at http:// nrs.harvard.edu/urn-3:HUL.InstRepos:dash.current.terms-of-use\#LAA

\section{Share Your Story}

The Harvard community has made this article openly available.

Please share how this access benefits you. Submit a story.

Accessibility 
NBER WORKING PAPER SERIES

POLITICAL PARTIES AND

THE BUSINESS CYCLE IN THE

UNITED STATES, 1948-1984

Alberto Alesina

Jeffrey Sachs

Working Paper No. 1940

NATIONAL BUREAU OF ECONOMIC RESEARCH

1050 Massachusetts Avenue

Cambridge, MA 02138

June 1986

The research reported here is part of the NBER's research program in Economic Fluctuations. Any opinions expressed are those of the authors and not those of the National Bureau of Economic Research. 
NBER Working Paper \#1940

June 1986

Political Parties and the Business Cycle in the United States, 1948-1984

\section{ABSTRACT}

This paper tests the existence and the extent of a politically induced business cycle in the U.S. in the post-World War II period. The cycle described in this paper is different from the traditional "political business cycle" of Nordhaus. It is based on a systematic difference between the monetary policies of the two parties in a model with labor contracts. From an explicit optimization problem we derive a system of equations for output and money growth. Then we successfully test the non-linear restriction imposed by the theory on the parameters of the system of equations. We cannot reject the hypothesis that money growth has been systematically different under the two types of administration and that this difference contributes to explain output fluctuations.

Alberto Alesina Department of Economics Harvard University Cambridge, MA 02138
Jeffrey Sachs

Department of Economics

Harvard University

Cambridge, MA 02138 


\section{Introduction}

The most famous attempt to model the relationship between political and economic cycles is the "political business cycle" theory formulated by Nordhaus (1975) and McRae (1977). Three crucial assumptions underly this approach: (i) the parties are "office motivated," in the sense that they care only about winning the elections, as in Downs (1957); (ii) voters are not forward-looking and have short memories, so that they can be systemat1cally fooled; ${ }^{1}$ and (1ii) the economy is described by an exploitable Phillips curve and the rational expectations critique is not taken into account.

The results derived by Nordhaus on the basis of these assumptions are well-known. The incumbent stimulates the economy and reduces unemployment close to election time in order to increase its chances of reelection. At the beginning of the new term, the inflationary effects of the pre-electoral expansion are eliminated with a recession. The behavior of the two parties is identical, and a cycle results in equilibrium.

The empirical evidence in support of the "political business cycle" theory 1 s rather weak for the U.S. case; in fact this theory has been rejected by several authors using post-Second World War U.S. data.

Given these rejections, an increasing number of empirical studies have moved toward a "partisan theory" of macroeconomic policy. The original proponent of this view was Hibbs (1977). This author argued that the Democratic Party in the U.S. and socialist parties in Europe have been more averse to unemployment and less averse to inflation than the Republican party in the U.S. and conservative parties in Europe. 
This theory has been tested empirically by Hibbs and others, using models based on an exploitable Phillips curve with no consideration for the rational expectations critique.

In this paper a model closely related to that of Alesina (1985a) is presented and tested on post-Second World War U.S. data. The model is based on a "partisan view" of political parties but, contrary to literature on the subject, it accounts for rational and forward-looking expectations. In this model only "unexpected policy" matters; the economy would exhibit policy neutrality features in a one-party system with no elections. However, the elections create an important source of uncertainty about the future: the economic agents do not know which party will win the following election. If the relevant expectations about monetary policy and inflation have to be formed before elections, they are based on the averages of the policies that the two parties are expected to follow once elected. If these policies are different the elected party creates a surprise, in the sense that its policy was not correctly predicted, since expectations accounted for the possibility of the election of the other party. The model, then, predicts that at the beginning of the term in office of the more expansionary party one should observe an output expansion above trend with high money growth. Instead, when the less expansionary party is elected, a recession with low money growth should be observed. There are no electoral surprises in the second part of any administration; hence, the model predicts policy neutrality. Then, in the second part of both types of administrations real variables should exhibit the same behavior (ceteris paribus). However, it will be shown that even in the second 
part of the term in office the rate of money creation should be different depending on the party in office.

Starting from an explicit maximization problem, we derive the reaction functions of the two parties and their time consistent policies and test the nonlinear restrictions on the parameters imposed by the theory. This procedure makes it possible to estimate directly the parameters of the objective functions of the two parties. The sample used covers the nine completed administrations of the post-World War II period, from President Truman through the first term of President Reagan.

The data do not reject the assumption that there is a difference between the objective functions of the two parties. The Democratic administrations have been relatively more concerned about the output target rather than the inflation/money creation target than the Republican administrations. Furthermore, the empirical results do not reject the hypothesis that systematic differences in output growth have occurred in the first half of the administrations and not in the second, in accordance with the theory. Thus, these results support a partisan view of monetary policy (and in general of macropolicy) rather than a political business cycle view. The only exception to this conclusion is perhaps the first Nixon administration, the behavior of which is probably better explained by a "political business cycle" view. The paper is organized as follows. Section 2 briefly reviews some of the recent empirical literature on the subject. Section 3 presents the model and derives the empirical implications of it. Section 4 provides empirical evidence in accordance with the qualitative implications of the model. In Section 5 the empirical estimates of the 
parameters of the model are presented and discussed. The concluding section summarizes briefly the major findings and identifies several open questions.

\section{Political Business Cycle Theory and Partisan Theory}

In his seminal article, Nordhaus (1975) provides suggestive empirical evidence in favor of the "political business cycle" hypothesis (henceforth PBC). This evidence appears favorable for the U.S. but rather mixed for several other countries. ${ }^{2}$ In particular, Nordhaus writes that the first Nixon administration is a "textbook example" of PBC because of the inflationary expansion skillfully placed close to the elections of 1972. However, the empirical work that has followed has led to the conclusion that the first Nixon administration was probably the only clear case of $\mathrm{PBC}$ in the post-Second World War period in the U.S. McCallum (1978), Golden-Poterba (1980), Beck (1982 and 1984), Abrams-Froyen-Waud (1983), Hibbs (1977 and 1985), Chapell-Keech (1986), and Havrileski (1985) all reject directly or indirectly the PBC hypothesis. Hibbs (1985), for example, concludes that there is "no persuasive evidence that presidential election years, viewed together, generally have been occasions of unusual monetary and fiscal expansions or of short run surges in output, real incomes, and employment." The lack of strong empirical support for the PBC has led Alt-Chrystal (1983) to conclude that "no one could read the political business cycle literature without being struck by the lack of supporting evidence." 3 On the other hand, Tufte (1978) finds some support for the PBC. This author finds evidence of short run increases in transfers in 
electoral years. Hibbs (1985) confirms these findings, but nonetheless they fail to provide convincing support for the general implications of the PBC for the cycle of inflation and unemployment or output.

The lack of empirical support for the PBC has led to an increasing amount of work directed toward testing a "partisan theory" (henceforth PT) of macroeconomic policy and, in particular, of monetary policy. This view was formulated in the seminal contribution of Hibbs (1977). This author argued that leftist parties in Europe and the Democratic party in the U.S. have been more likely to choose a point on the Phillips curve with higher inflation and less unemployment than conservative parties in Europe and the Republican party in the U.S. Hibbs claims that the lower middle class and the working class benefit from a policy of low unemployment and relatively high inflation and these social groups tend to support the left. This view is clearly summarized by Paul Samuelson, who wrote in 1977: "We tend to get our recessions during Republican administrations.... The difference between the Democrats and the Republicans is the difference in their constituencies. It's a class difference ... the Democrats constitute the people, by and large, who are around the median incomes or below. They are the ones whom the Republicans want to pay the price of fighting inflation. The Democrats [are] willing to run with some inflation ... the Republicans are not" (Samuelson (1977)). The events that followed 1977 hardly could have changed Samuelson's view of the subject. Very similar views are expressed by Okun (1973), in disagreement with Stigler (1973). Stein (1985) stresses that employment and growth were always top priority for Democratic administrations after the Second World War, while inflation was the first priority for Republican administrations. 
Kiewiet (1985) tests the hypothesis that voters in the U.S. did in fact recognize the Democratic party as the one that fights unemployment and the Republican party as the one that fights inflation. The author finds that this hypothesis is supported by the empirical evidence.

Beck (1984) finds virtually no evidence in favor of the PBC and concludes that monetary policy has been looser under Democratic presidents than under Republican presidents; however, he finds that the Kennedy and first Nixon administrations do not fit this pattern. On the basis of these two exceptions he raises a word of caution with respect to the PT as formulated by Hibbs. Beck claims that different administrations of the same party have behaved differently; therefore, "administrations" more than parties are what really count. 4 Nevertheless, despite this important consideration the PT is not rejected by Beck's results. Furthermore, note that only the Nixon exception is really problematic for the PT; this administration probably behaved in a way more consistent with the PBC than with the PT. In the case of the Kennedy administration the crucial fact is that the economy was stimulated through fiscal rather than monetary expansion; this does not imply that the PBC approach would fit the Kennedy administration better than the PT.

Havrileski (1985) finds that changes of administrations from Republican to Democratic have been asssociated with upward jumps in money growth; conversely, downward jumps are observed when a Republican administration is elected after a Democratic one. 5

Chapell-Keech (1986) refer to results on unemployment that are "quite similar in magnitude to those reported by Hibbs." The authors also suggest that differences in the rates of unemployment under the 
administrations of the two parties tend to become smaller in the latter part of the term. The explanation given for this phenomenon is very similar to that suggested in this paper but the authors do not present an explicit formalization of this problem.

Finally, note that systematically different monetary policies between parties should imply a systematically different behavior of the exchange rate. Preliminary results of Hansson (1985) show that since the beginning of the floating regime, the U.S. dollar has shown a tendency toward appreciation during Republican administrations and toward depreciation during the Democratic administration of President Carter.

Virtually all the empirical literature on policy choices on a Phillips curve utilize models in which little attention, if any, is devoted to incorporating rational expectations. ${ }^{6}$ The presumption of many authors was that in models characterized by policy neutrality most of the interest for the PT or for the PBC is lost. Secondly, almost no attempt has been made to estimate the parameters of the policymakers' objective functions. In fact, an explicit maximization problem of parties' objective functions generally is not solved in order to derive testable reduced forms. ${ }^{7}$ The model presented in the next section incorporates both features: rational, forward-looking agents and an explicit solution of the policymakers' maximization problem.

\section{The Model}

There are two parties, denoted with obvious reference party $D$ and party R. The two parties assign different weights to two policy 
targets: an inflation rate or money growth target and an output growth target. The policy instrument controlled by the policymaker is the rate of money creation. A quadratic specification for the objective functions of the two parties is adopted so that the loss function of the two parties can be written as (the superscripts characterize the party):

$$
\begin{aligned}
& z^{D}=\sum_{t=0}^{\infty} q^{t}\left[\frac{a}{2}\left(m_{t}-\psi(t)\right)^{2}+\frac{\tilde{b}}{2}\left(y_{t}-\phi\right)^{2}\right] \\
& z^{R}=\sum_{t=0}^{\infty} q^{t}\left[\frac{c}{2}\left(m_{t}-\psi(t)\right)^{2}+\frac{a}{2}\left(y_{t}-\phi\right)^{2}\right]
\end{aligned}
$$

where $\mathrm{m}=$ rate of money growth; $\mathrm{y}=$ rate of growth of GNP; $a, \tilde{b}, c, \phi$, and $\mathrm{d}$ are non-negative parameters; and $\mathrm{q}$ is the discount factor, positive but less than one.

The economy is described by the following equation for output growth:

$$
y_{t}=\bar{y}(t)+\gamma\left(m_{t}-m_{t}^{e}\right)
$$

Equation (3) incorporates the basic properties of a Lucas supply function in which only unexpected nominal shocks affect real variables. In (3) we indicated with $\vec{y}(t)$ the rate of growth generated by the economy in the absence of monetary shocks; this rate is not assumed constant. Also, $m_{t}^{e}$ is the rational expectation of $m_{E}$ formed in period $t-1$ on the basis of the information available at that time. The objective functions (1) and (2) are in the information set of the agents. 
The objective functions could have been written with an inflation target instead of the money growth target, and the supply equation could have been written as a function of unexpected inflation. This alternative specification could have been closed by a simple money demand equation such as:

$$
\mathrm{m}_{\mathrm{t}}=\Pi_{\mathrm{t}}+\alpha \mathrm{y}_{\mathrm{t}}
$$

where $I I$ is the inflation rate and $\alpha$ is a constant. The shortcut adopted here keeps the algebra simpler, saves degrees of freedom, and it should not affect qualitatively the empirical results. The choice of a target in terms of rate of growth of output instead of a level of GNP (or of unemployment) is imposed by theoretical and empirical considerations. If a target in level of output were chosen, one would have needed a more complex dynamic structure for the supply equations, involving one or more lags, for example. This procedure would have reduced the already scarce degrees of freedom. Furthermore, the solution of the model and the computation of the Nash equilibrium would have been much more problematic and difficult to test empirically. This is an open question to be addressed in future research.

The targets on money growth and output growth are assumed identical for the two parties: the difference in the objective functions is constrained to be in the relative weights attributed to identical targets. This restriction, imposed to conserve degrees of freedom, should not affect the nature of the results. Finally, the targeted level of money growth, $\psi(t)$, is allowed to change over time, to reflect velocity shifts in (4). 
In this paper, no distinction is made between the "administration" and the Central Bank. The implicit assumption, shared with most of the literature on the $\mathrm{PBC}$ versus the $\mathrm{PT}$, is that the administration has some control over monetary policy, despite the relative independence of the Central Bank. Weintraub (1978) argues that this is, in fact, a realistic assumption. Stein (1985) provides several examples of cases in which the Fed has accommodated the "desire" of the President. Grier (1985) discusses and tests the degree of effective independence of the Federal Reserve from both the Congress and the President. The degree of independence of the Federal Reserve from the administration is an important and open question that would probably deserve a separate treatment. Here it is assumed that the Federal Reserve cannot choose a monetary policy independently from the administration.

As long as $\phi>\bar{y}(t)$ and $b$ and $d$ are positive, both parties face the problem of dynamic inconsistency of optimal monetary policy, as pointed out originally by Kydland-Prescott (1977). If the targeted level of output growth, $\phi$, is higher than the growth rate generated by the market, $\bar{y}(t)$, the policymaker has an incentive to generate policy surprises in order to approach the target. In fact, by substituting (3) into (1) and (2), one gets:

$$
\begin{aligned}
& z^{D}=\sum_{t=0}^{\infty} q^{t}\left[\frac{a}{2}\left(m_{t}-\psi(t)\right)^{2}+\frac{5}{2}\left(\bar{y}(t)-\phi+\gamma\left(m_{t}-m_{t}^{e}\right)\right)^{2}\right] \\
& z^{R}=\sum_{t=0}^{\infty} q^{t}\left[\frac{c}{2}\left(m_{t}-\psi(t)\right)^{2}+\frac{a}{2}\left(\bar{y}(t)-\phi+\gamma\left(m_{t}-m_{t}^{e}\right)\right)^{2}\right]
\end{aligned}
$$

It is more convenient to rewrite (5) and (6) as: 


$$
\begin{aligned}
& z^{D}=\sum_{t=0}^{\infty} q^{t}\left[\frac{a}{2}\left(m_{t}-\psi(t)\right)^{2}+\frac{b}{2}\left(m_{t}-m_{t}^{e}-k(t)\right)^{2}\right] \\
& z^{R}=\sum_{t=0}^{\infty} q^{t}\left[\frac{c}{2}\left(m_{t}-\psi(t)\right)^{2}+\frac{d}{2}\left(m_{t}-m_{t}^{e}-k(t)\right)^{2}\right]
\end{aligned}
$$

where $b=\delta r^{2}, d=\partial \gamma^{2}$, and $k(t)=(\bar{\phi}-\bar{y}(t)) / \gamma$. In order to 1dentify the problem of dynamic inconsistency, consider, for example, party D acting as "dictator," with no elections. If this party could make a binding commitment it would choose to commit to the rule:

$$
m_{t}=\psi(t)
$$

This rule is obtained by minimizing (5), taking account of the rationality of expectations, i.e., $m_{t}=m_{t}^{e}$. However, binding commitments are hardly available: the pollcymaker can always change both its mind and the law. Then the time consistent rate of money growth has to be found by minimizing (5) taking expectations as given. This procedure leads to:

$$
m_{t}=\frac{a}{a+b} \psi(t)+\frac{b}{a+b}\left(m_{t}^{e}+k(t)\right)
$$

Solving for rational expectations, one gets:

$$
m_{t}^{e}=m_{t}=\psi(t)+\frac{b}{a} k(t)
$$


In (11) the term $b / a k(t)$ is the inflationary bias introduced into the economy by the absence of binding commitments. Note that this bias would be zero if and only if either $b=0$ and/or $\bar{y}(t)=\phi$ (that is, $k(t)=0)$. The bias is higher the higher is the targeted rate of growth of GNP relative to the rate of growth generated by the economy, and the higher the weight attributed by the policymaker to the output target relative to the money growth target. Note that, irrespective of the level of the time-consistent rate of money growth, output growth is at the level determined by the economy without policy intervention, because money creation is perfectly anticipated. Furthermore, a fall in the rate of growth of output generated by the market Implies a higher rate of inflation. In fact, a fall in $\bar{y}(t)$ implies an increase in $k(t)$. The implication is that a negative trend of output growth could be associated with an increasing trend of inflation, if the preferences of the policymakers do not change.

Let us now consider the interaction of the two parties. It is assumed that elections take place every two periods and are held at the beginning of the period. After the elections of, say, time $t$, the elected party chooses its policy for period $t$ (i.e., $m_{t}$ ). The electoral outcomes are uncertain. Party $\mathrm{D}$ is elected with probability $\mathrm{P}$ and party $\mathrm{R}$ with probability 1 - $\mathrm{P}$. The probability $\mathrm{P}$ is taken as an exogenous parameter and it is "common knowledge"; thus, it is in the information set of agents. Alesina (1985b) shows how this assumption could be generalized to the case of rational and forward-looking voters. The crucial assumption is that, if voters are forward-looking (as they should be!) and they know the objective functions of the two parties, the policy chosen by the elected party at time $t$ does not influence its 
chances of reelection at time $t+2$. In fact, the probability of electing a party is a function of the expected future policies of the two parties. If voters know the objective functions of the two parties, they do not need the information of today's policy to form expectations about tomorrow's policies.

If party $D$ is elected, it minimizes (6). The first order condition 1s:

$$
m_{t}^{D}=(1-g) \psi(t)+g\left(m_{t}^{e}+k(t)\right)
$$

where $g=b /(b+a)$. If party $R$ is elected, it minimizes (7). The corresponding first order condition is:

$$
m_{t}^{R}=(1-h) \psi(t)+h\left(m_{t}^{e}+k(t)\right)
$$

where $h=d /(c+d)$. Expectations are given by:

$$
\begin{array}{ll}
m_{t}^{e}=P m_{t}^{D}+(1-P) m_{t}^{R} & \text { if } t \text { is an election year; } \\
m_{t+1}^{e}=m_{t+1}^{D} & \text { if party } D \text { is elected at time } t ; \\
m_{t+1}^{e}=m_{t+1}^{R} & \text { if party } R \text { is elected at time } t .
\end{array}
$$

Equation (14) underscores the idea that there is uncertainty in expectation formation only in the first period of an administration.

The assumption that administrations last two periods implies for the U.S. that a period is of two years. This assumption is consistent, for example, with the existence of overlapping labor contracts of an average length of two years (see Taylor, 1980, or Fischer, 1977). In 
more general terms, this assumption requires some form of stickiness in the price system such that the economy does not adjust "too quickly" to an unexpected monetary shock. ${ }^{8}$

For the empirical estimation of the model it is assumed that both $\bar{y}(t)$ and $\psi(t)$ are linear trends:

$$
\begin{aligned}
& \psi(t)=\overline{\mathrm{m}}+\sigma t \\
& \bar{y}(t)=\bar{y}-\tilde{\mathrm{B}} t
\end{aligned}
$$

The assumption that the optimal rate of money growth is not constant, but increasing over time, captures the positive time trend in this variable. Then, given (12), (13), (14), (15), and (16), some algebra establishes that:

$$
\begin{aligned}
& y_{t}^{D 1}=\bar{y}+\gamma(1-P) \frac{(g-h) k}{1-P g-(1-P) h}+\gamma \frac{(g-1) \beta t}{1-P g-(1-P) h} \\
& y_{t}^{R 1}=\bar{y}+\gamma P \frac{(h-g) k}{1-P g-(1-P) h}+\gamma \frac{(h-1) \beta t}{1-P g-(1-P) h} \\
& y_{t}^{D 2}=\bar{y}-\gamma \beta t \\
& y_{t}^{R 2}=\bar{y}-\gamma \beta t \\
& m_{t}^{D 1}=\bar{m}+\sigma t+\frac{g k}{1-P g-(1-P) h}+\frac{g}{1-P g-(1-P) h} B t \\
& m_{t}^{R 1}=\bar{m}+\sigma t+\frac{h k}{1-P g-(1-P) h}+\frac{h}{1-P g-(1-P) h} B t \\
& m_{t}^{D 2}=\bar{m}+\sigma t+\frac{g}{1-g} k+\frac{g}{1-g} \beta t \\
& m_{t}^{R 2}=\bar{m}+\sigma t+\frac{h}{1-h} k+\frac{h}{1-h} \beta t
\end{aligned}
$$


where $k \equiv(\phi-\bar{y}) / \gamma$ and $\beta \equiv \tilde{\beta} / \gamma$. The superscripts D1, D2, R1, and R2

stand for the first and second periods of $D$ and $R$ administrations.

Equations (17) to (24) embody several empirical implications:

1. In the second half of both administrations there are no policy surprises; therefore, output growth is at the level determined by the market without policy intervention, $\bar{y}-\tilde{\beta} t$.

2. If $g>h$ there is a recession in the first half of an $R$ administration and an expansion above trend in the first half of a D administration (equations (17) and (19)). The deviations of output growth from trend, $\bar{y}-\tilde{\beta} t$, are bigger the more different are $g$ and $h$, i.e., the greater the difference in the relative weights attributed by the two parties to the two targets.

3. The more unexpected the electoral outcome, the bigger is the deviation of output growth from trend. For example, if $\mathrm{P}$ is high and party $R$ is elected, the model predicts a deep recession. The reverse holds if party $D$ is elected and $P$ is low. The more surprising is the electoral result, the greater the discrepancy between the expected $m$ and its actual value.

4. If $g>h$ the time consistent rate of money growth is higher for party D than for party $\mathrm{R}$ in both periods (equations (21) to (24)).

5. If $\mathrm{g}>\mathrm{h}>0$, in $\mathrm{a} \mathrm{D}$ administration the rate of money creation deviates from trend more in the second period than in the first; the opposite holds for the administrations of party $R$ (equations (21) to (24)). If $\mathrm{h}=0$ there are no deviations from trend in both periods of a Republican administration. The intuition is that in a $D$ administration expectations are adjusted upward in the second period, 
when there is certainty that the more expansionary party is in office. Therefore, the time consistent rate of money creation is higher: the policymaker is forced to accommodate these expectations, in order to avoid a recession. The opposite holds for the less expansionary party. If $h=0$, party $R$ is not affected by the problem of dynamic inconsistency of monetary policy, because this party would have no incentive to generate policy surprises. In this case the optimal monetary policy is time-consistent for this party.

The outcome characterized by equations (17) to (24) is the oneshot discretionary equilibrium without binding commitments. This equilibrium could be improved upon if reputational strategies were used in the repeated game. This issue is extensively explored by Alesina (1985a). In this paper only the one-shot Nash case is considered.

\section{Preliminary Evidence}

This section shows that the qualitative empirical implications of the model are consistent with U.S. data for the post-Second World War period.

\section{a. GNP Growth}

Table 1 displays the average rate of growth of GNP at 1972 prices per year for the first and second half of the administration of the two parties. The averages are taken over the period 1949-1984, thus including nine administrations ( 4 Democratic and 5 Republican). In the 
Table 1

Average Rate of Growth of GNP

(Constant Prices)

1949-1984

First Half Second Half

Democratic Administrations

Republican Administrations

5.0

1.2

3.9

4.0

Source: Economic Report of the President (1985) 
second half of the administrations of both parties the average rate of growth is almost identical, around 4 percent. The rate of growth in the first half of Democratic administrations has been higher than in the second half, while the rate of growth in the first half of Republican administrations has been much lower than that of the second half.

An even more suggestive piece of evidence is presented in Tables 2 and 3. Table 2 shows the rate of growth of GNP for each year considered in the sample. If one assumes that after a new administration takes office there is a lag of a few months between the implementation of the new policies and their full effect on GNP growth, then in the second year, more than in the first, the results of the policies of the new administration should become apparent. The difference in the performance of the two types of administrations in the second year is rather striking. The same observation is reinforced by Table 3 which compares the rate of growth of the second year with the average rate of growth of the third and fourth years. These tables are selfexplanatory. In the second years of all the Republican administrations there has been a negative GNP growth. The only two other years of negative growth in the period examined have been 1974 and 1980, both years affected by the oil shocks (Table 2). On the contrary, the second years of Democratic administrations show sustained growth well above the second half of the term.

The following simple regression accounts for the preceding observations. The average GNP growth per-year is regressed over the four dummies for the four periods considered, first and second half of Democratic administrations, first and second half of Republican administrations, and a time trend. The variable D1 is a dumy assuming 
Table 2

Rate of Growth of GNP

(Constant Prices)

Democratic Administrations

\begin{tabular}{lcccr} 
& \multicolumn{5}{c}{ Year } \\
\cline { 2 - 5 } & First & Second & Third & Fourth \\
\hline Truman & 0.5 & 8.7 & 8.3 & 3.7 \\
Kennedy & 2.6 & 5.8 & 4.0 & 5.3 \\
Johnson & 6.0 & 6.0 & 2.7 & 4.6 \\
Carter & 5.5 & 5.0 & 2.8 & $-0.3^{*}$ \\
\hline Average & 3.7 & 6.4 & 4.5 & 3.3 \\
\hline Average & \multicolumn{3}{c}{3.9} \\
First/Second Halves & & 5.0 & & \\
\hline
\end{tabular}

$\underline{\text { Republican Administrations }}$

\begin{tabular}{lcrc}
\hline \multicolumn{4}{c}{ Year } \\
\hline First & Second & Third & Fourth \\
\hline 3.8 & -1.2 & 6.7 & 2.1 \\
1.8 & -0.4 & 6.0 & 2.2 \\
2.8 & -0.2 & 3.4 & 5.7 \\
5.8 & -0.6 & $-1.2^{*}$ & 5.4 \\
2.5 & -2.1 & 3.7 & 6.8 \\
\hline 3.3 & -0.9 & 3.7 & 4.4 \\
\hline & & & \\
& & & 4.0 \\
\hline
\end{tabular}

Source: See Table 1

* Oil shocks 
Table 3

Rate of Growth of GNP

(Constant Prices)

\begin{tabular}{lcc}
\hline & Second Year & Average Third and Fourth Year \\
\hline Truman & 8.7 & 6.0 \\
Eisenhower I & -1.2 & 4.4 \\
Eisenhower II & -0.4 & 4.0 \\
Kennedy & 5.8 & 4.6 \\
Johnson & 6.0 & 3.6 \\
Nixon I & $-0.2 *$ & $4.5^{*}$ \\
Nixon II & $-0.6^{*}$ & $2.1^{*}$ \\
Carter & 5.0 & $1.2^{*}$ \\
Reagan I & -2.1 & 5.2 \\
\hline
\end{tabular}

Source: See Table 1

* Oil shooks 
the value of 1 in the first half of a Democratic administration and zero otherwise, and R1 (R2) are dummies assuming the value of 1 in the first (second) half of a Republican administration. The result is the following (the t-statistics are in parentheses):

$$
\begin{aligned}
& \mathrm{y}_{\mathrm{t}}=4.46+1.05 \mathrm{D} 1-2.64 \mathrm{R} 1+0.29 \mathrm{R} 2-0.06 \mathrm{t} \\
& \begin{array}{llll}
(5.41) & (1.17) \quad(-3.10) & (0.34) & (-1.05)
\end{array} \\
& \mathrm{R}^{2}=0.65, \quad \text { D.W. }=2.39
\end{aligned}
$$

The coefficient on the second half Republican (R2) is clearly insignificant, confirming that the data do not show any difference between the second halves of both administrations. The dummy for the first half of Republican administrations has, instead, a strongly significant negative coefficient, as predicted by the theory. The dummy for the first half of Democrat administrations (D1) has the right sign even though is not statistically strongly significant. There is a negative but not statistically significant trend.

Analogous results are obtained by the following additional test. The quarterly GNP at constant 1972 prices has been regressed on eight lagged values, a time trend, a dummy for the oil shocks, and two dummies for the first half of the administrations of the two parties. In Table 4 the results are displayed. The dummy REL assumes the value of 1 in the first eight quarters of each Republican administration and zero otherwise. The coefficient of this variable is negative and significant at the 1 percent level. The dummy DEL assumes the value of 1 in the first eight quarters of each Democratic administration and zero otherwise. The coefficient of this variable is positive as predicted by 
Table 4

Quarterly GNP

(1949-1984)

\begin{tabular}{lcc}
\hline Variables & Coefficients & T-Statistics \\
\hline C & 13.50 & 1.44 \\
GNP $(-1)$ & 1.25 & 14.7 \\
GNP $(-2)$ & -0.2 & -1.45 \\
GNP $(-3)$ & -0.16 & -1.13 \\
GNP $(-4)$ & -0.06 & 0.44 \\
GNP $(-5)$ & -0.004 & -0.31 \\
GNP $(-6)$ & 0.10 & 0.73 \\
GNP $(-7)$ & -0.04 & -0.29 \\
GNP $(-8)$ & 0.007 & 0.08 \\
TIME & 0.23 & 1.29 \\
OILSH & -4.88 & -1.61 \\
REL & -6.08 & -2.79 \\
DEL & 2.21 & 0.96 \\
\hline
\end{tabular}

D.W. $=2.05, R^{2}=0.99$

Source: Citibank database 
the theory but it is not strongly slgnificant. The variable OILSH accounts for the effects of the two oil shocks. ${ }^{9}$

An additional important empirical observation along these 1 ines is shown in Table 5. This table displays the timing of the beginning of all the recessions in relation to the preceding elections. A few months after the election of every Republican administration a recession started. There have been no recessions in the first half of a Democratic administration. A recession started the same month of the election of Truman in November 1948, and, therefore, two months before this administration took office. The other two recessions started in the second half of the Carter administration, at the time of the second oil shock and in the last year of the second administration of Eisenhower. Leaving aside the Truman recession, of dubious origin, five of the seven recessions fit the theory and two do not. Note that the two that do not fit also contradict the $\mathrm{PBC}$ approach because they occur in the second halves of two administrations. The crucial fact that discriminates in favor of the approach of this paper rather than the PBC is that none of the Democratic administrations had recessions at the beginning of their terms, as the PBC theory predicts.

\section{b. Money Growth}

The model implies that the time consistent rate of money creation of Republican administrations is lower than that of Democratic administrations, in both periods (first and second half). The following regression allowing for a linear trend in money growth does not reject this implication: 
Table 5

Post-Second World War Recessions

\begin{tabular}{|c|c|c|}
\hline Through & Beginning of Contraction & $\begin{array}{l}\text { Previous Election } \\
\text { (Party Elected) }\end{array}$ \\
\hline October, 1949 & November, 1948 & $\begin{array}{c}\text { November, } 1948 \\
\text { (D) }\end{array}$ \\
\hline May, 1954 & June, 1953 & $\begin{array}{c}\text { November, } \\
(R)\end{array}$ \\
\hline April, 1958 & July, 1957 & $\begin{array}{c}\text { November, } 1956 \\
(R)\end{array}$ \\
\hline February, 1961 & April, 1960 & $\begin{array}{c}\text { November, } \\
\text { (R) }\end{array}$ \\
\hline November, 1970 & October, 1969 & $\begin{array}{c}\text { November, } \\
(\mathrm{R})\end{array}$ \\
\hline March, .1975 & December, $1973^{*}$ & $\begin{array}{c}\text { November, } \\
\text { (R) }\end{array}$ \\
\hline July, 1980 & January, $1980^{*}$ & $\begin{array}{c}\text { November, } 1976 \\
\text { (D) }\end{array}$ \\
\hline November, 1982 & May, 1981 & $\begin{array}{c}\text { November, } \\
(R)\end{array}$ \\
\hline
\end{tabular}

Source: National Bureau of Economic Research

* Oil shocks 


$$
\begin{aligned}
& \mathrm{m}_{\mathrm{t}}=1.49-1.14 \mathrm{R}+0.39 \mathrm{t} \\
& \begin{array}{lll}
(2.18) & (-1.83) \quad(6.52)
\end{array} \\
& \mathrm{R}^{2}=0.74, \quad \text { D.W. }=1.96 \\
& \mathrm{~m}=\text { average rate of growth of } \mathrm{M} 1 \text { per year (biannual averages) }
\end{aligned}
$$

The dummy variable for Republican administrations, $R$, assumes the value of 1 during Republican administrations and zero otherwise. The coefficient of this varaible is negative, as predicted by the theory, and statistically significant at the 5 percent level. As expected there is a highly significant trend. Beck (1984) pointed out that two administrations do not quite fit the partisan theory of monetary policy: the Kennedy administration and the first Nixon administration, because of the tight monetary policy of the former and the 1971-1972 monetary expansion of the latter. This is indeed the case. By introducing in the regression (26) a dummy, $\mathrm{KN}$, that assumes the value of -1 in the two periods of the Kennedy administration and 1 in the second period of the Nixon administration, one obtains:

$$
\begin{aligned}
& \mathrm{m}_{\mathrm{t}}=\underset{(3.61)}{2.13}-\underset{(-3.30)}{1.82} \mathrm{R}+\underset{(3.00)}{2.03 \mathrm{KN}}+\underset{(7.70)}{0.37} \mathrm{t} \\
& \mathrm{R}^{2}=0.84, \quad \text { D.W. }=2.56
\end{aligned}
$$

The coefficient of $R$ becomes bigger in absolute value and more significant; the coefficient of $\mathrm{KN}$ is also very significant. Thus, equation (27) identifies the two outliers of the regression (26). The second empirical implication for money growth is that one should observe a larger deviation from trend in the second half of a Democratic administration than in the first. In a Republican 
administration, instead, the opposite should hold if $h>0$. The following regression tests these implications:

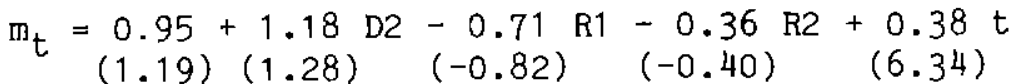

$$
\begin{aligned}
& \mathrm{R}^{2}=0.77, \quad \text { D.W. }=1.81
\end{aligned}
$$

D2 is a dummy assuming the value of 1 in the second halves of Democratic administrations and zero otherwise. As predicted by the theory, there is more money creation in the second part of a Democratic administration than in the first: the coefficient of D2 is in fact positive and large, although statistically not strongly significant. For the Republican administration the implications of the theory are rejected: the relative magnitude of the two coefficients is opposite from what the theory predicts and the two coefficients are not significant. The reason for this imperfect $\mathrm{fit}$ is, again, to be attributed to the Kennedy and first Nixon administrations. In fact, by introducing the dummy $\mathrm{KN}$ into the preceding regression we obtain:

$$
\begin{aligned}
& m_{t}=1.58+1.19 \mathrm{D} 2-1.20 \mathrm{R} 1-1.23 \mathrm{R} 2+2.04 \mathrm{KN}+0.37 \mathrm{t}
\end{aligned}
$$

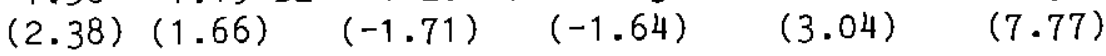

$$
\begin{aligned}
& R^{2}=0.81, \quad \text { D.W. }=2.47
\end{aligned}
$$

The fit of the regression greatly improves. There is virtually no difference between the coefficients of $\mathrm{R} 1$ and $\mathrm{R} 2$. This result is consistent with the prediction of the model for the case of $h=0$ (see equations (17) to (24)). Again, there is more money creation, on 
average, in the second half of Democratic administrations than in the first.

Given that the model attributes so much emphasis to unexpected monetary shocks, the unexpected money variable, DMR, constructed by Barro (1978) has been analyzed. This variable is obtained by Barro from the residual of a regression of the rate of money growth, M1, on several lagged variables assumed to be in the relevant information set of the economic agents. ${ }^{10}$ Biannual averages of this variable (DMR) are reported in Table 6 (this variable is not available after 1976). Eleven observations have the expected sign, negative for Republican and positive for Democratic administrations. Only three observations do not fit. According to the following simple regression we can reject the hypothesis of no significant difference in the "money surprises" under the two types of administration:

$$
\begin{aligned}
& \mathrm{DMR}_{\mathrm{t}}=\underset{(1.41)}{0.43}-\underset{(-2.47)}{(.00 \mathrm{R}} \\
& \mathrm{R}^{2}=0.75, \quad \text { D.W. }=2.16
\end{aligned}
$$

Table 5 does not suggest that "surprises" have occurred only in the first half of the term in office. However, given the different approach followed by Barro in modeling expectations, the data do not have to conform necessarily to this pattern.

\section{Estimation of the Model}

The empirical evidence in the preceding section suggests that the model is broadly in accordance with the data. In fact, the cross- 
Table 6

Barro's Unexpected Money

Biannual Averages

(Rate of Growth in Percent)

\begin{tabular}{lr}
\hline Truman & 0.30 \\
& 1.35 \\
Eisenhower I & -1.00 \\
& -0.20 \\
Eisenhower II & -0.85 \\
& -1.25 \\
Kennedy & -0.85 \\
& 0.15 \\
Johnson & 0.35 \\
& 1.30 \\
Nixon & 0.45 \\
& -0.45 \\
Nixon/Ford & 0.25 \\
\hline
\end{tabular}

Source: Barro (1978) 
equation restrictions imposed by the model cannot be rejected. The system of equations (14) to (21) has been estamated using LSQ and testing the nonlinear restrictions on the parameters imposed by the theory. The only modification from equations (17) to (24) is given by the introduction of a dummy variable in the output growth equation to account for the two oil shocks. ${ }^{11}$

For reasons that will become immediately clear, two results of the estimation are presented. Table 7 reports the results obtained by estimating all the parameters of the model except $k$, fixed at the value of $1.3 .^{12}$ The log likelihood test does not reject the restrictions imposed by the theory at the 5 percent confidence level.

The estimated values of the parameters are consistent with the theory. In particular, $\mathrm{h}=\mathrm{d} \mathrm{Y}^{2} /(\mathrm{c}+\mathrm{d})$ is insignificantly different from zero, while $g=5 \gamma^{2} /(a+b)$ is positive and significant $(0.51)$. Note that the regressions (28) and (29) were also consistent with the assumption of $h=0$ in the cost function of party $R$. The relative magnitude of $g$ and $h$ does not reject the hypothesis that the Democratic administrations have attributed more weight to the output target than the Republican administrations, that instead have been concerned mainly (or only, strictly speaking) with the money growth target. This is the crucial result that discriminates the approach followed in this paper from the PBC. The latter approach would predict that one should not observe any difference between the behavior of the two administrations.

The estimated value of $\gamma$ (the effect of unanticipated money on output growth) is rather high (3.08). This value is, however, not inconsistent with the findings of Barro (1978). His results cannot be directly compared with the results of this paper because of the 
Table 7

Estimation of the Model: I

\begin{tabular}{lcc}
\hline Parameters & Estimates & T-Statistics \\
\hline$\vec{y}$ & 4.26 & 8.47 \\
$\gamma$ & 3.08 & 1.91 \\
$P$ & 0.71 & 5.62 \\
$\mathrm{~g}$ & 0.51 & 1.85 \\
$\mathrm{~h}$ & -0.09 & -0.09 \\
$\mathrm{~B}$ & 0.004 & 0.29 \\
$\mathrm{a}$ & -0.03 & -1.49 \\
$\overline{\mathrm{m}}$ & 0.35 & 0.24 \\
$\sigma$ & 0.39 & 7.31 \\
\hline
\end{tabular}

Log of likelihood function: -53.1

Degrees of freedom: 11 
different specification of the output equation, but the two estimates have the same order of magnitude. ${ }^{13}$ The estimated values of $\gamma$ and $\bar{y}$, respectively 3.08 and 4.26 , and the value of $k$, fixed at 1.3 , imply that the targeted level of GNP growth $(\phi)$ is about 8 percent. This value is reasonable given that $1 \mathrm{t}$ is a "bliss point" in the objective functions of the two parties. The trend in output growth is negative but insignificant, implying that the "natural" rate of GNP growth is around 4 percent per year.

The estimated value of $P$, the probability of electing a Democratic administration, is high, 0.71 , implying that Republican administrations have always been elected with a certain amount of "surprise." The value of this parameter is due to the fact that the deviation from trend of output growth at the beginning of Republican administrations has been on average bigger (in absolute value) than the same deviations at the beginning of Democratic administrations. This observation was already apparent from the result of the simple regressions (25) and (26) and from Table 4. In the simple model used this asymmetry can only be captured by a high P, implying, ceteris paribus, more surprise when a Republican president is elected, and, therefore, stronger effects on output of monetary policy. However, the same phenomenon could be explained by an asymmetric effect of negative versus positive monetary shocks due, for example, to different degrees of price flexibility upward or downward. The issue of the relation between poll predictions about electoral outcomes and effects of policies needs further investigation. Needless to say, the probability $P$ is, in general, different in every election. 
The remaining parameters have the expected sign and order of magnitude. In particular, there is a positive and significant trend in the money growth ( $\sigma$ is positive and significant); the oil shocks have affected negatively output growth in a significant way (the parameter a is referred to the dummy variable for the oil shocks).

Let us now consider the results obtained by estimating all the parameters, including $k$. The results are reported in Table 8 . The most important difference in the two sets of results (Tables 7 and 8 ) is in the value of $\gamma$ that is much higher and, probably, unrealistically high in the new estimations (4.97). Instead, the estimated value of $k$ is much lower than 1.3 , the value to which it was fixed in the preceding estimation. Furthermore, the t-statistics for $\gamma$ and $k$ are very low; on the contrary, $\gamma$ was highly significant where $k$ was exogenously fixed (Table 7). Note, also, that the value of the log likelihood function is virtually identical in the two regressions, implying that the log likelihood test is also accepted at the 5 percent level. This result is probably an indication of weak identification for the parameters $\gamma$ and k. Consider, in fact, the output growth equations, here reproduced for convenience:

$$
\begin{aligned}
& y_{t}^{D 1}=\bar{y}+\gamma(1-P) \frac{(g-h) k}{1-P g-(1-P) h}+\gamma \frac{(g-1) \beta t}{1-P g-(1-P) h} \\
& y_{t}^{D 2}=\bar{y}-\gamma \beta t \\
& y_{t}^{R 1}=\bar{y}+\gamma \frac{P(h-g) k}{1-P g-(1-P) h}+\gamma \frac{(h-1) B t}{1-P g-(1-P) h} \\
& y_{t}^{R 2}=\bar{y}-\gamma \beta t
\end{aligned}
$$


Table 8

Estimation of the Model: II

\begin{tabular}{lcc}
\hline Parameters & Estimates & T-Statistics \\
\hline $\bar{y}$ & 4.26 & 10.01 \\
$\gamma$ & 4.97 & 0.98 \\
$\mathrm{P}$ & 0.81 & 5.13 \\
$\mathrm{~g}$ & 0.90 & 6.08 \\
$\mathrm{~h}$ & -1.6 & -0.22 \\
$\mathrm{k}$ & 0.17 & 0.59 \\
$\mathrm{~B}$ & -0.001 & -0.32 \\
$\mathrm{a}$ & -1.29 & -1.91 \\
$\overline{\mathrm{m}}$ & 0.58 & 0.68 \\
$\sigma$ & 0.39 & 7.56 \\
\hline
\end{tabular}

Log of likelihood function: -52.44

Degrees of freedom: 10 
In these equations the parameter $k$ always enters multiplied by $\gamma$. The parameter $\gamma$ also appears multiplied by $\beta$, but $\beta$ is insignificantly different from zero. Therefore, the identification of $\gamma$ and $k$ is left exclusively to the money growth equation. Due to the lack of degrees of freedom, this identification is probably weak.

\section{Summary and Extensions}

This paper has provided empirical support to the "partisan view" of monetary policy. First of all, we could reject the hypothesis that macroeconomic outcomes have been the same under Democratic and Republication administrations in the post-Second World war period in the U.S. We also could not reject the hypothesis that deviation of output growth from trend occurred mostly in the first halves of the term, as predicted by the theory; the rate of growth of money, instead, has been systematically different for the entire term, also as predicted by the theory. The conclusions that have been inferred from these results are essentially two. In the first place, Democratic administrations seemed relatively more concerned with an output target than with a money growth/inflation target. Second, the real effects of new pollcies are stronger in the $\mathrm{f}$ irst halves of new administrations. If a more expansionary administration is elected, it can take advantage of a short run Phillips curve. However, once the economy has fully adjusted to the new regime, the same expansionary policy has little if any effect on real variables, i.e., the Phillips curve is more (or completely) vertical. Conversely, there are short run output losses when an administration more concerned with inflation is elected. These results, 
then, reject Nordhaus' formulation of the "political business cycle" and support a partisan view of macropolicy.

The analysis of this paper could be extended in several directions. First, the dynamic structure of the model could be enriched, although problems of degrees of freedom would arise. Second, attention could be devoted to the issue of predictability of electoral results. The model identifies a relation between degree of "surprise" in electoral results and real effects of monetary policy. This issue could be addressed directly by using data on prediction polls. Third, systematic difference in policies of the two parties could be analyzed by looking at different variables. For example, the stock market and the financial markets may react to electoral results. Fourth, different countries could be analyzed using the framework of this paper. Some complications would arise for parliamentary systems in which the timing of elections is an endogenous variable. 


\section{Footnotes}

1. Nordhaus (1975) and McRae (1977) assume irrational voting behavior in the sense that voters can be systematically fooled by the incumbent party. Rogoff-Sibert (1985) have obtained some results in the same spirit as those of Nordhaus-McRae in a model with rational but imperfectly informed voters. This point is also addressed by Cukierman-Metzler (1985).

2. The empirical evidence presented by Nordhaus is rather weak for Australia, Canada, the United Kingdon, Sweden, France, and Japan. More favorable observations for the PBC were found in Germany and New Zealand, besides the U.S.

3. The same passage is quoted by Beck (1984).

4. Beck (1982) also questions the magnitude of Hibbs' (1977) results; nevertheless, the two authors agree on the qualitative features of them.

5. Havrileski (1983) considers these effects on M2.

6. Important exceptions are McCallum (1978) and Havrileski (1985).

7. A notable exception is Abrams-Froyen-Waud (1983). These authors, however, address issues related to budget deficits and their response to economic conditions.

8. Barro (1978) finds that lagged values of unexpected monetary shocks affect the current level of output.

9. This variable assumes the value of 1 in 1974-1975, and in 1980, zero otherwise. The results of this regression are not sensitive to alternative specifications of the dummy accounting for the oil shocks.

10. These varlables are lagged money growth, lagged unemployment, and a measure of federal budget deficit (Barro, 1978, equation (1), p. 551).

11. This variable takes the values of 1 in 1973-1974, 1975-1976, and 1979-1980, zero otherwise.

12. The estimates are non-sensitive to small variations of this value.

13. Barro (1978) presents the following regression:

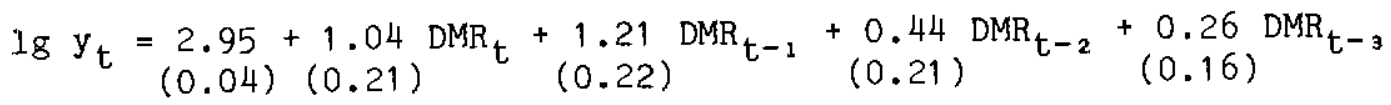

$$
\begin{aligned}
& \begin{array}{l}
+0.55 \mathrm{MIL}_{\mathrm{t}} \\
\underset{(0.09)}{(0.0354 \mathrm{t}}(0.0004)
\end{array}
\end{aligned}
$$


Standard errors are in parentheses. $y=\log$ of GNP at 1972 prices; DMR = unexpected M1. MIL is the ratio of military personnel to the male population aged 15 to 44 . 


\section{References}

Abrams, R., R. Froyen, and R. Waud (1980), "Monetary Policy Reaction Functions, Consistent Expectations and the Burns Era," Journal of Money Credit and Banking, February, pp. 30-43.

Alesina, A. (1985a), "Macroeconomic Policy in a Two-Party System as a Repeated Game," unpubl ished, November.

Alesina, A. (1985b), "Credibility and Policy Convergence in a Two-Party System with Rational Voters," unpublished, November.

Alt, J. and A. Chrystal (1983), Political Economy, Berkeley University Press, Berkeley.

Barro, R. (1978), "Unanticipated Money, Output and the Price Level in the United States," Journal of Political Economy, August, pp. 549-580.

Beck, N. (1982), "Parties, Administrations and American Macroeconomic Outcomes," American Political Science Review, March, pp. 83-94.

Beck, N. (1984), "Domestic Political Sources of American Monetary Policy: 1955-82," Journal of Politics, August, pp. 787-815.

Chapell, H. and W. Keech (1986), "Party Differences in Macroeconomic Policies and Outcomes," American Economic Review, May, pp. 71-74.

Downs (1957), An Economic Theory of Democracy, Harper and Row, New York.

Fischer, S. (1977), "Long-Term Contracts, Rational Expectations and the optimal Money Supply Rule," Journal of Political Economy, February, pp. 191-206.

Golden, D. and J. Poterba (1980), "The Price of Popularity: The Political Business Cycle Reexamined," American Journal of Political Science, November, pp. 696-714.

Grier, K. (1985), "Congressional Preference and Federal Reserve Policy," Center for the Study of American Business, Washington University, St. Louis, Working Paper No. 95.

Hansson, A. (1985), "Political Regime Changes and Exchange Rate Determination," unpubl ished, December.

Havrileski, T. (1985), "A Partisanship Theory of the Current Monetary Regime," unpublished, August.

Hibbs, D. (1977), "Political Parties and Macroeconomic Policy," The American Political Science Review, December, pp. 1467-1487. 
Hibbs, D. (1985), The American Political Economy : Electoral Policy and Macroeconomis in Contemporary America, Harvard University Press, forthcoming.

Kiewielt, R. (1985), Micropolitics and Macroeconomics, Chicago University Press, Chicago.

Kydland, F. and E.C. Prescott (1977), "Rules Rather than Discretion: The Inconsistency of Optimal Plans," Journal of Political Economy, June, pp. 473-490.

McCallum, B. (1978), "The Political Business Cycle: An Empirical Test," Southern Journal of Economics, January, pp. 504-515.

McRae, D. (1977), "A Political Model of the Business Cycle," Journal of Political Economy, April, pp. 239-264.

Nordhaus, N.D. (1975), "The Political Business Cycle," Review of Economic Studies, April, pp. 169-190.

Okun, A. (1973), "Comments on Stigler's Paper," American Economic Review, Papers and Proceedings, May, pp. $17 \overline{2-177 .}$

Rogoff, K. and A. Sibert (1985), "Equilibrium Political Business Cycles," unpublished, December.

Samuelson, P. (1977), "Some Dilemmas in Economic Policy," Challenge, March/Apri1, pp. 45-52.

Stein, H. (1985), Presidential Economics, Simon and Schuster, New York.

Stigler, G. (1973), "General Economic Conditions and National Elections," American Economic Review, Papers and Proceedings, May, pp. $160-167$.

Stuart, J. and D. Allen (1986), "The Federal Reserve and the Electoral Cycle," Journal of Money Credit and Banking, February, pp. 88-94.

Taylor, J. (1980), "Aggregate Dynamics and Staggered Contracts," Journal of Political Economy, February, pp. 1-23.

Tufte, E. (1978), "Political Control of the Economy," Princeton University Press, Princeton.

Weintraub, R. (1978), "Congressional Supervision of Monetary Policy," Journal of Monetary Economics, April, pp. 341-362. 
Data Sources

Citibank Database.

Economic Report of the President 1985.

Business Conditions Digest, U.S. Department of Commerce, Bureau of Economic Analysis, various issues.

National Bureau of Economic Research, Timing of Recessions in the U.S. 